\title{
Udveksling og gave i det fjerde eu-angelium og dets dys-angelium
}

\author{
Eksegese af Joh 3,16
}

\author{
Professor mso, ph.d. \\ Jesper Tang Nielsen, Københavns Universitet
}

\begin{abstract}
This article is a tribute to Ole Davidsen on the occasion of his retirement from the University of Aarhus. Theories of gift-giving and exchange have been an important factor for Davidsens interpretation of New Testament theology and recently for his understanding of the Gospel of John. I present Davidsens semiotic formulation of the conceptual frame constituted by giving and taking and his understanding of the fundamental New Testament structures. Davidsen insists that the Gospel of John involves a sacrificial understanding of the death of Jesus. He argues that God gives his son in order to repay for an illegitimate take. Therefore he proposes an Adam-myth as background for the Gospel of John. This view is challenged in the article. I argue on the basis of an exegesis of John 3:16 that the illegitimate take consists in a lack of recognition of God, i.e. a degressive cognitive act. That is the underlaying dys-angelium to which the Johannine eu-angelium responds. The gift in the Gospel of John is recognition of God brought forth by Jesus, i.e. a progressive cognitive act.
\end{abstract}

Keywords: Ole Davidsen, Jacques Derrida, Gift-giving, Gospel of John, Recognition, John 3:16

Gaveteorier har i næsten hundrede år spillet en central rolle i antropologiske studier. De har derfra vundet indpas i andre social- og humanvidenskaber, og der er opstået en selvstændig filosofisk diskussion om den rette forståelse af gaven og dens mulighed eller umulighed. ${ }^{2}$ Teorierne og diskussionerne er siden blevet bragt i anvendelse i teolo-

\footnotetext{
1. Artiklen er en lettere gennemarbejdet og udvidet version af mit oplæg ved lektor, dr.theol. Ole Davidsens afskedsarrangement, 7. oktober 2015, Aarhus Universitet. Jeg vil gerne benytte lejligheden til at takke arrangøren, lektor, ph.d. Kasper Bro Larsen for invitationen og endnu engang udtrykke min taknemmelighed til Ole Davidsen for alt, hvad jeg har lært af ham.

2. Se fx artiklerne i samlebindene Aafke E. Komter, The Gift: An Interdisciplinary Perspective (Amsterdam: Amsterdam University Press); Alan D. Schrift, The Logic of the Gift. Toward an Ethic of Generosity (New York, London: Routledge 1997).
} 
giske, særligt systematisk-teologiske, sammenhænge. ${ }^{3}$ For nylig er de også inddraget i bibel-teologiske arbejder. I den danske eksegese er det ikke mindst Ole Davidsen, man kan takke for introduktionen af også disse teoridannelser. ${ }^{4}$

Ofte optræder Joh 3,16 i disse sammenhænge. Verset får gerne status som det ultimative udtryk for Guds gave både i Johannesevangeliet og i Det Nye Testamente som helhed. Således også det populære navn "den lille Bibel", som synes at udtrykke den indsigt, at hele Bibelens budskab sammenfattes i det vers. Også i Davidsens arbejder er der tendenser i den retning. Det gælder både for hans opfattelse af den nytestamentlige teologi og af Johannesevangeliet. Imidlertid er der grund til at se nærmere på versets indhold. Særligt for Johannestolkningen har det stor betydning.

\section{Udveksling og gaver i teorien}

Som bekendt skal socialantropologen M. Mauss krediteres for præsentationen af gavens økonomi. ${ }^{5}$ Hans undersøgelser viste, at traditionelle samfund ikke baseres på økonomiske transaktioner, som det er tilfælde i den industrialiserede verden, men derimod på gaveudveksling, hvis betydning er langt videre end den reciprokke overdragelse af værdier. Gaven indebærer økonomiske, religiøse, følelsesmæssige og mange andre strukturer og er således en total social begivenhed.

3. Fx Bo K. Holm, Gabe und Geben bei Luther. Das Verhältnis zwischen Reziprozität und reformatorischer Rechtfertigungslehre (Berlin: de Gruyter 2006); Niels Henrik Gregersen, "Generositetens teologi", DTT 71 (2008), 77-99; Jan-Olav Henriksen, Desire, Gift and Recognition. Christology and Postmodern Philosophy (Grand Rapids, Mich.: W.B. Eerdmanns Pub. 2009); Risto Saarinen, "The Language of Giving in Theology", NZSTh 52 (2010), 268-301 og bidragene i John D. Caputo, Michael J. Scanlon (red.), God, the Gift, and Postmodernism (Bloomington: Indiana University Press 1999).

4. Ole Davidsen, "Geben und nehmen: Narrativer Austausch im Neuen Testament", JBTh 27 (2013), 121-150; "Give and Take: Narrative Exchange in the New Testament. Part One \& Two” Aarhus 2012 (internetpublikation tilgængelig via http://pure.au.dk/portal/da/persons/ole-davidsen(fc595e91-97db-427c-957e11a990c7b1fe)/publications.html besøgt 20.10.2015). Se også Troels EngbergPedersen, "Gift-Giving and Friendship: Seneca and Paul in Romans 1-8 on the Logic of God's Xápıs and Its Human Response”, HTR 101 (2008), 15-44; Anne Katrine de Hemmer Gudme, “Tomhændet må ingen se mit ansigt! Gavens teologi i Det Gamle Testamente” DTT 78 (2015), 300-319.

5. Marcel Mauss, "Essai sur le don. Forme et raison de l'échange dans les sociétés archaïques" i Marcel Mauss, Sociologie et anthropologie (Paris: Presses Universitaire de France 1950), 143-279. Til præsentationen af Mauss' og Levi-Strauss' opfattelser se Davidsen (2013), $121 \mathrm{f}$. 
C. Levi-Strauss udvikler og udbreder Mauss' resultater til at gælde andre samfund end arkaiske. ${ }^{6}$ Det forhold, at gaver indebærer forpligtelse og reciprocitet, er ikke begrænset til traditionelle samfund. Forpligtelsen til at give, modtage og gengælde gaver synes at være et universelt kulturelt fænomen.

At gaver indgår i forpligtende relationer, hvor en gave påfører modtageren en forpligtelse til at gengælde gaven, er grunden til den almene drøftelse af gavens mulighed. Filosofisk er det spørgsmålet om den såkaldt rene gave, der har interesse. Kan en gave gives, hvis den, som påvist af socialantropologerne, altid forpligter modtageren til at give en modgave, om ikke andet så i form af taknemmelighed. I den filosofiske sammenhæng forstås det således, at en gave, hvor giveren forventer gengæld, ikke er en gave, men et bytte, dvs. en økonomi. Pointen er, at modgaven opløser gaven. En gave er ikke "ren", hvis den indgår i en forpligtende reciprocitet. Det er ligeledes dette forhold, der kan forekomme problematisk ved brugen af gaveteorier i den protestantiske systematiske teologi, da gave-begrebet indebærer en reciprocitet, som lutherske ideer om den rene nåde skulle udelukke. ${ }^{7}$

Blandt de filosofiske bidrag kan der være grund til kort at præsentere J. Derridas. ${ }^{8}$ Som vanligt gennemtænker han temaet med en vilje til at radikalisere problemerne mest muligt. Han kommer frem til gavens umulighed. Den rene gave kan ikke gives, for så vil giveren nødvendigvis forvente en form for modgave, hvorved gaven er blevet til en investering. Men den kan heller ikke modtages, for så vil modtageren uvægerligt blive bragt i gældsforhold til giveren, og så er gaven et lån. Kort sagt - Derrida bruger mange flere ord - er gaven umulig $i$ en relation mellem giver og modtager; eller rettere: fordi gaven etablerer en relation mellem giver og modtager bliver den umulig. Gavens natur vil nemlig altid bestemme relationen som udvekslingsøkonomisk, og i en sådan findes gaver ikke, men kun lån, gæld og gengæld. Betingelserne for gavegivning udelukker gaven. Skulle der gives en gave, mener Derrida, skulle det være en, som hverken giver eller modtager kender til. Giveren må ikke vide, at han giver; modtageren ikke, at han modtager. Så snart man ved, at en gave er en gave, er det ikke længere en gave (Derrida 1991, 26f). For Derrida er det meget vigtigt, at han dermed ikke har sagt, at gaver ikke findes. De kan bare ikke vise sig som gaver. ${ }^{?}$

6. Claude Levi-Strauss, Les structures élémentaires de la parenté (Paris: Presses Universitaire de France 1967), 61-79.

7. Jf. fx Saarinen (2010), 300.

8. Jacques Derrida, Donner le temps. 1: La fausse monnaie (Paris: Galilée 1991).

9. Jf. Caputo \& Scanlon (1999), 60. 
Derridas tilgang til spørgsmålet er umiskendeligt 'derridask'. Men det kan også hævdes, at den er tydeligt kantiansk. Havde det ikke været for Kants opfattelse, at den moralske handling ikke må have nogen egennytte overhovedet og derfor må gøres af pligt og ikke tilbøjelighed, ville problemet næppe stille sig på samme måde for Derrida og hans filosofiske diskussionspartnere. ${ }^{10}$ Men man kan videre spørge, om Kants opfattelse er luthersk. Kants holdning, at en altruistisk handling skal være rettet alene mod den anden og helt uden egeninteresse, kan meget vel være en moralfilosofisk version af Luthers mistro til gode gerninger, som vil fortjene sig til Guds nåde, der skænkes helt ubegrundet og helt uden forpligtelser (gratis). ${ }^{11}$ Man kan ikke undgå at komme på den tanke, at Derrida i denne sammenhæng gennemfører en luthersk læsning af gavebegrebet. ${ }^{12}$

\section{Udveksling og gaver i Det Nye Testamente}

Uanset den filosofiske benægtelse af gavens mulighed har gaveteorierne vundet indpas i den nytestamentlige eksegese med væsentlige konsekvenser for en mulig nytestamentlig teologi. Davidsens særlige bidrag er en analyse af gaven inden for den konceptuelle ramme, der sættes af forholdet mellem "give" og "tage" (Davidsen 2013). Således placeres "gave" over for "tægt". De to begreber kan ikke forstås isoleret, da de konceptuelt forudsætter hinanden. En gave modsvares af en tægt; tægt af en gave. Fra disse begreber kan Davidsen endvidere på grundlag af sin semiotiske tilgang fremanalysere endnu to begreber: "ikke-gave" og "ikke-tægt" eller "ikke-give" og "ikke-tage". I troskab mod traditionen fra læremesteren A.-J. Greimas stiller Davidsen disse

10. Således Pierre Bourdieu om Derridas position. Pierre Bourdieu, "Marginalia - Some Additional Notes on the Gift", 241 n. 5, i Schrift (1997), 231-241; jf. Engberg-Pedersen (2008), 16.

11. Om Luthers indflydelse på Kants filosofi, se Bernard Wand, "Religious Concepts and Moral Theory: Luther and Kant", Journal of the History of Philosophy 9 (1971), 329-348; jf. Friedrich Paulsen, "Kant der Philosoph des Protestantismus", Kant-Studien 4 (1900), 1-31; Bruno Bauch, "Luther und Kant", Kant-Studien 9 (1904), 351-492; Heinrich Ostertag, "Luther und Kant", Neue kirchliche Zeitschrift 36 (1925), 765-807.

12. Det må tilføjes, at denne indvending angår Derridas fortolkning af gaven i Mauss' forstand som interpersonel udveksling af konkrete objekter. Hans udredninger har dog et langt mere grundlæggende sigte, der angår den fænomenologiske tilgang i det hele taget. Se diskussionen med Jean-Luc Marion i Caputo \& Scanlon (1999), 54-78. Hertil også Ingolf U. Dalferth, "Umsonst. Vom Schenken, Geben und Bekommen”, StTh 59 (2005), 83-103. Om Derrida i det ærinde kan siges at være påvirket af kantianske eller lutherske tankestrukturer nok tvivlsomt. 
positioner op i en firkant. ${ }^{13}$ Han kan derved afdække logikken bag fire mulige handlinger: En legitim gave ("give" / "tage"), dvs. at give til en, der tager imod; legitim tægt ("tage" / "give"), dvs. at tage fra en, der giver; en illegitim gave ("give" / "ikke-tage"), dvs. at give til en, der ikke tager imod; illegitim tægt ("tage" / "ikke-give"), dvs. at tage fra en, der ikke giver. De legitime forhold er harmoniske, mens de illegitime er disharmoniske. Som Mauss og Levi-Strauss viste gennem socialantropologiske undersøgelser, har Davidsen demonstreret gennem en semiotisk analyse, at gaven som et socialt fænomen implicerer en relation mellem mindst to subjekter. Udveksling konstituerer sociale forhold som venskab og fjendskab.

Teologisk betydningsfuldt er disse kategorier, fordi de ifølge Davidsen gemmer korsets gåde (Davidsen 2013, 136). Jesu korsdød kan betragtes som enhver af disse muligheder (legal gave: offer; illegal gave: selvmord; legal tægt: henrettelse; illegal tægt: mord). Samtlige mulighederne afprøves i de nytestamentlige skrifter. Alene inden for Johannesevangeliet findes alle fire i udsagn fra de jødiske modstandere: legal gave: jøderne ønsker, at Jesus skal dø for folket $(11,50)$; illegal gave: jøderne spørger, om Jesus vil tage sit eget liv $(8,22)$; legal tægt: jøderne vil have ham dømt til døden som en forbryder $(19,7)$; illegal tægt jøderne søger at slå ham ihjel $(7,1)$.

Selvfølgelig er den første mulighed den foretrukne i Det Nye Testamente. Det hænger sammen med den fortælling, som korsdøden finder sted i. Det er en af Davidsens store fortjenester at have påvist den fundamentale narrative struktur, som organiserer de nytestamentlige udsagn om Jesu død. ${ }^{14}$ Som i alle andre traditionelle fortællinger er det styrende forløb fireleddet: Manipulation (helten pålægges en opgave, dvs. han forbindes med "burden"), Kompetence (helten opnår den nødvendige evne til at udføre opgaven, dvs. han forbindes med "kunnen"), Performance (helten løser opgaven, dvs. han forbindes

13. Algirdas-Julien Greimas, Joseph Courtés, Semiotique. Dictionnaire raisonné de la théorie du langage (Paris 1979), art. Carré sémiotique.

14. Davidsen (2013), 133f. Specifikt for Markusevangeliets vedkommende se "Narrativitet og eksistens. Et religionssemiotisk bidrag til bestemmelsen af den narrative Jesus i Markusevangeliet”, DTT 49 (1986), 241-267; The Narrative Jesus. A Semiotic Reading of Mark's Gospel (Aarhus: Aarhus Universitetsforlag 1993). Specifikt for Paulus' vedkommende: "Den strukturelle Adam/Kristus-typologi. Om Romerbrevets grundfortælling”, DTT 55 (1992), 241-261; “The Structural Typology of Adam and Christ: Some Modal-semiotic Comments on the basic Narrative of the Letter to the Romans", i Søren Giversen \& Peder Borgen (red.), Hellenistic Judaism and the New Testamente (Århus: Aarhus University Press 1995), 244-262; "Adam og Kristus: Om Romerbrevets grundfortælling (Rom 5,12-21)”, i Kasper Bro Larsen \& Troels Engberg-Pedersen (red.), Paulusevangeliet: Nye perspektiver på Romerbrevet (København: Forlaget Anis 2015), 131-160. 
med "gøren"), Sanktion (helten belønnes for udførelse, dvs. han forbindes med "væren"). ${ }^{15}$ Jesus-fortællingens grundlæggende narrative skema kan således gengives i et basalt forløb: Gud har påbudt Jesus at give sit liv (Manipulation) og giver ham ånden som hjælper (Kompetence). Jesus lider korsdøden (Performance) og belønnes derfor med opstandelsen (Sanktion). Gennem dette narrative gennemløb opnår Jesus status som den opstandne og himmelske Guds søn. Fordi der ligger et guddommeligt påbud til grund for den handling, som Jesus lydigt udfører, er korsdøden en legitim gave, et offer.

Men er påbuddet legitimt? Har Gud ret til at give Jesus buddet om at give sit liv? Ja, for det er en af Davidsens væsentlige pointer, at der bag den eu-angeliske fortælling ligger en anden, en dys-angelisk fortælling. Det er begrundet i det grundlæggende narratologiske forhold, som særligt C. Bremond har præsenteret, at narrative handlinger er valoriseret inden for en narrativ ontologi. ${ }^{16}$ Enhver handling påvirker en væren inden for det narrative univers. Derfor kan man operere med to narrative subjekter: et handlingssubjekt ("l'agent"/"subject of doing") og et værenssubjekt ("le patient"/"subject of being"). Handlingssubjektet påvirker værenssubjektets status ved sin handling. Bremonds anayser viser, at handlingen i overensstemmelse med den grundlæggende valorisering kan have en af fire forskellige former: Progression: en handling, der fremmer liv; Protektion: en handling, der beskytter liv; Degression: en handling, der ødelægger liv; Depression: en handling, der forhindrer liv. Som prototyper kan "gave" og "tægt" bestemmes som hhv. en progressiv og en degressiv handling (Davidsen 2013, 127-129). Man kan derfor bestemme eu-angeliet som en fortælling, hvor handlingssubjektet forårsager en progression i værenssubjektets status, mens dys-angeliet er en fortælling, hvor handlingssubjektet forårsager en degression i værenssubjektets status. Udtrykt med udvekslingsbegreberne kan man sige, at eu-angeliets legitime gave forbedrer den almene værensstatus, fordi handlingen tilføjer værenssubjektet noget godt, en gevinst. Derimod forværrer dys-angeliets illegitime tægt den almene værensstatus, fordi handlingen tilføjer værenssubjektet noget ondt, et tab.

Dys-angeliet, som er en forudsætning for eu-angeliet, finder Davidsen udtrykt i den paulinske version af Adam-fortællingen (Rom 5) (Davidsen 2013, 131 n. 12; jf. Davidsen 1992; 1995). I den udsættes Gud for en illegitim tægt. Grundstrukturen i Paulus' gengivelse af historien om syndefaldet er som i den gammeltestamentlige (Gen 2-3) fortælling. Den følger det almindelige narrative skema. I ud-

15. Jf. Greimas \& Courtés (1979), art. Narratif (parcours -).

16. Claude Bremond, Logique du récit (Paris: Éditions du Seuil 1973). 
gangspunktet sættes Adam over for et forbud. Han må ikke spise af kundskabens træ (Manipulation). Adam adlød imidlertid ikke forbuddet (Performance). Gud straffer derfor mennesket med døden (Sanktion). ${ }^{17}$ Med de udviklede udvekslingsteoretiske termer ser den narrative struktur således ud: Forbuddet kræver en ikke-tagen, men handlingssubjektet Adam tager, hvad han ikke måtte. Det er en illegitim tægt, fordi Adams “tagen” står over for Guds “ikke-given”. Således kom synden ind i verden. Ved den bliver værenssubjektet, Gud, påført et tabt. Eftersom mennesket Adam fungerer som en mytisk person, hvis handlinger har konsekvenser for hele menneskeheden, bliver mennesket på grund af den illegitime tægt pålagt en skyld. Denne skyld må mennesket indfri gennem en legitim gave (menneskets "given" svarer til Guds retmæssige "tagen"), ellers har Gud ret til at tilføje mennesket en legitim tægt (Guds "tagen" svarer til menneskets pligtige "given"). Derfor kom døden ind i verden, som syndens sold. Nu er det evige liv, der var en mulighed, før Adam forbrød sig mod forbuddet, blevet umuligt (Davidsen 1992, 256). Således er den dys-angeliske udgangssituation for den eu-angeliske fortælling etableret.

Med det bagvedliggende dys-angelium er det klart, at den eu-angeliske struktur, som er den anden del af Adam-Kristus-typologien i Rom 5, indeholder et legitimt påbud. Der er netop tale om, at Gud iværksætter den legitime gave, som skal udligne tabet. Påbuddet er, at Kristus skal give sit liv (Manipulation). Kristus skal give en legitim gave, fordi Gud har et retmæssigt krav. Kristus' "given” står over for Guds berettigede "tagen". Kristus er lydig mod påbuddet og giver sit liv i korsdøden (Performance). Gud accepterer Kristus' gave og skænker ham livet i opstandelsen (Sanktion). Hermed er Guds legitime tægt annulleret. Adams forbrydelse var en mytisk begivenhed med konsekvenser for hele menneskeheden, og det er Kristus' lydighed også. Således kom livet ind i verden som lønnen for den lydige korsdød. Det evige liv er atter oprettet som en mulighed, selv om det indtil Kristus' lydighed mod påbuddet var umuligt (Davidsen 1992, 258). I den eu-angeliske fortælling om den legitime gave betales skylden for den illegitime tægt, og den legitime tægt afblæses derfor.

Ydermere er det Guds egen søn, der foretager det offer, som kræves, for at Gud skal blive god igen og annullere den tægt, som han var berettiget til. Mennesket er altså skyldig over for Gud, og Gud betaler selv sine skyldnere. Hvorfor gør han det? Davidsen svarer ikke direkte, men referencen til Joh 3,16 (Davidsen 2013, 133) indeholder

17. Kompetencefasen optræder ikke altid som en selvstændig fase. I dette tilfælde og i andre af de nytestamentlige narrative forløb ligger den implicit som en særlig modalisering af Adams kunnen, dvs. ikke-kunnen. Davidsen (2015), 143 note 4. 
formodentlig hans svar: På grund af kærlighed! Det er kristendommens genistreg ifølge Nietzsche:

Gott selbst sich für die Schuld des Menschen opfernd, Gott selbst sich an sich selbst bezahlt machen, Gott der Einzige, der vom Menschen ablösen kann, was für den Menschen selbst unablösbar geworden ist - der Gläubiger sich für seinen Schuldner opfernd, aus L i e b e (sollte man's glauben? -), aus Liebe zu seinem Schuldner!... ${ }^{18}$

\section{Udveksling og gaver i Johannesevangeliet}

For Davidsen er denne forståelse fundamental for nytestamentlig teologi. Han finder den præsenterede udvekslingsteoretiske tolkning af korsdøden på grundlag af Adam-myten ikke bare hos Paulus, men også som baggrund for Markusevangeliet. ${ }^{19} \mathrm{Og}$ han finder den i Johannesevangeliet. ${ }^{20}$ Joh 3,16 optræder som kvintessensen af den tolkning. Det kan det selvfølgelig gøre løsrevet fra sin kontekst i Johannesevangeliet, men Davidsen argumenterer for, at forestillingen ligger i Johannesevangeliet selv og kommer emblematisk til udtryk i formuleringen "Således elskede Gud verden, at han gav (edôken) sin søn, for at enhver, der tror, (hina pas ho pisteuôn) ikke skal fortabes, men have evigt liv" $(3,16)$. Heri skulle den grundlæggende udvekslingsteoretiske struktur ligge: Gud giver sin søn hen i døden for at skænke mennesker det evige liv. Som hos Paulus og i Markusevangeliet konstitueres frelsen ifølge Davidsen også i Johannesevangeliet gennem en progressiv handling. som forandrer den fortabte situation, som menneskeverdenen befinder sig i. Det er afgørende for Davidsen, at den handling finder sted i fortællingens pragmatiske (af Davidsen til tider kaldet pragmiske) dimension. ${ }^{21}$ Derfor finder han også

18. Friedrich Nietzsche, Zur Genealogie der Moral, Zweiter Abhandlung, $\$ 21$.

19. "Adam-Christ Typology in Paul and Mark: Reflections on a Tertium Comparationis”, i Eve-Marie Becker, Troels Engberg-Pedersen, Mogens Müller (red.), Mark and Paul: Comparative Essays Part II. For and Against Pauline Influence on Mark (Berlin: de Gruyter 2014), 243-273.

20. "The Lord, the Lamb, and the Lover: The Gospel of John as a Mixture of Spiritualized Narrative Genres", i Kasper Bro Larsen (red.), John as Genre Mosaic (Göttingen: Vandenhoeck \& Ruprecht 2015), 125-156.

21. Sondringen mellem en pragmatisk og en kognitiv dimension af narrative tekster stammer fra A.-J. Greimas. Algerdas-Julien Greimas, Joseph Courtés, "The Cognitive Dimension of Narrative Discourse", New Literary History 7 (1976), 433447. Den pragmatiske dimension består af det konkrete forløb i fortællingen, mens den kognitive dimension omhandler forståelsen af forløbet. Man kan derfor fore- 
i Johannesevangliet en sakrificiel eller soningsteologisk forståelse af korsbegivenheden, som ikke mindst kommer til udtryk i fremstilling af Jesus som et (påske)lam (Davidsen 2015, 141). ${ }^{22}$

Den tolkning af Johannesevangeliet er ikke uomstridt. Det ved Davidsen godt. I en note skriver han:

The sacrificiel interpretation of Jesus' death has been a scandal to people since antiquity, but nowadays it is painful even to Christian believers. Exegetes and other interpreters are therefore [min kursiv] looking for alternative readings, and find the Gospel of John convenient for such an endeavor, since the cognitive function dominates the account (...). Maybe the author of John's Gospel was trying to deconstruct and reinterpret a common sacrificial understanding in early Christianity. The difficulty is, however, that the story of John's Gospel tends to lose intelligibility if there is no pragmic action causing the reversal from the world's misfortune to fortune. We have the same problem with the presupposed pre-story about the events or actions that caused the world's deficiency, the reversal from fortune to misfortune, and that explicate its need for salvation. (...) The Gospel of John, however, never reveals how this deficiency was established. The world is under Satan's rule, but the author never tells his audience why. The most obvious explanation would be that the pre-story is the Adam story, as presupposed in a double sense. The author and the implied audience not only know the Adam story, they are also familiar with the community's assenting reception and use of it. (Davidsen 2015, 128 note 4).

Uden at gå ind i en detaljeret forskningshistorisk drøftelse, er der grund til at nævne, at dette næppe er en præcis beskrivelse af situa-

stille sig en fortælling, der alene har en pragmatisk dimension, men ikke en kognitiv. Det omvendte er ikke muligt, da den kognitive dimension må forholde sig til en pragmatisk, selv om den pragmatiske dimension ikke behøver at være andet end en anledning for den kognitive dimension. Jf. Greimas \& Courtés (1979), art. cognitif. 22. Davidsens tolkning af $1,29.36$ med 19,14 er imidlertid problematisk alene af den grund, at påskelammet ikke er et offer, se fx Christina Schlund, "Kein Knochen soll gebrochen werden." Studien zu Bedeutung und Funktion des Pesachfest in Texten des frühen Judentums und im Johannesevanglium (WMANT 107; Neukirchen-Vluyn 2005); Reimund Bieringer, "Das Lamm Gottes, das die Sünde der welt wegnimmt (Joh 1,29): Eine kontextorientierte und redaktionsgeschichtliche Untersuchung auf dem Hintergrund des Passatradition als Deutung des Todes Jesu im Johannesevangelium", i Gilbert van Belle (red.), The Death of Jesus in the Fourth Gospel (BEThL 200, Leuven: Leuven University Press 2007), 199-232; Jesper Tang Nielsen, "The Lamb of God: The Cognitive Structure of a Johannine Metaphor", i Jörg Frey, Jan G. Van der Watt, Ruben Zimmermann, Imagery in the Gospel of John: Terms, Forms, Themes, and Theology of Johannine Figurative Language (WUNT 200; Tübingen: Mohr Siebeck 2006), 217-256. 
tionen. ${ }^{23}$ Inden for Johannes-forskningen er alternative forståelser af Jesu død, herunder dens kognitive funktion, til større forargelse end den traditionelle korsteologiske opfattelse. Der anvendes mere energi på at finde soningsteologi eller korsteologi i Johannesevangeliet, end der bruges på at bortforklare den. Toneangivende forskere kan acceptere, at Johannesevangeliet ikke indeholder traditionel soningsteologi, men påstår alligevel, at "die Sache der Sühne" findes deri. ${ }^{24}$ Uanset hvad "die Sache der Sühne" præcist måtte betyde (det er ikke helt klart), kan udtrykket meget vel anvendes til at beskrive Davidsens pointe. Jesu frivillige offerdød er den pragmatiske handling, som etablerer vendingen fra fortabelse til frelse ved at bære menneskets retfærdige straf. Davidsen finder det bl.a. udtrykt i den legitime gave, som Joh 3,16 efter hans mening omtaler. Gud giver sin søn hen i døden, hvorved frelsen etableres. Af samme grund må der være forudsat et dys-angelium, der forklarer den fortabte situation, der er evangeliets udgangspunkt. Johannesevangelium må således grundlæggende fortælle samme historie som Markusevangeliet, ellers tenderer det mod uforståelighed.

\section{Udveksling og gaver i Joh 3,16}

Davidsens tolkning kan prøves på en eksegese Joh 3,16. Som fremlagt dukker det vers op på centrale steder i hans analyser af den generelle nytestamentlige struktur og i hans tolkning af Johannesevangeliet. Gerne løsrevet fra sin johannæiske sammenhæng. Men spørgsmålet er, hvad Joh 3,16 betyder i sin kontekst.

Verset optræder i dialogen med Nikodemus, farisæeren, der kommer til Jesus om natten $(3,1)$. Imidlertid er Nikodemus på dette tidspunkt af samtalen umærkeligt forsvundet. Hans sidste replik falder i vers 9 og derefter glider dialogen på typisk johannæisk maner over $\mathrm{i}$ en monolog. Umiddelbart før v. 16 har den johannæiske Jesus refereret til ophøjelsen af kobberslangen under ørkenvandringen for at sige, at menneskesønnen skal ophøjes på samme måde, for at enhver som tror skal have evigt liv $(3,14 \mathrm{f})$. Herefter følger kærlighedserklæ-

23. Davidsen har aldrig opfattet det som sin opgave at skrive forskningshistorier. Som han siger: "Nogle eksegeter er gode til at lave forskningsoversigter, andre laver den forskning, som indgår i disse oversigter."

24. Jörg Frey, "Edler Tod - wirksamer Tod - stellvertretender Tod - heilschaffender Tod: Zur narrativen und theologischen Deutung des Todes Jesu im Johannesevangelium", i Gilbert van Belle (red.), The Death of Jesus in the Fourth Gospel (BEThL 200; Leuven: Leuven University Press 2007), 63-94 (92). 
ringen til verden $(3,16)$, som atter følges af en redegørelse for Jesu sendelse: Gud har ikke sendt ham for at dømme verden, men for at verden skal frelses ved ham. Den, der tror, dømmes nemlig ikke, men den, der ikke tror, er allerede dømt, fordi han ikke er kommet til tro på Guds enbårne søns navn (3,17f). Efter dette følger en definition af dommen: At lyset er kommet til verden, og menneskene elskede mørket frem for lyset $(3,19)$. Dette føres i afsnittets sidste vers over i gerningskategorier: Enhver, der gør det onde, kommer ikke til lyset, for at hans gerninger ikke skal afsløres. Men den, der gør sandheden, kommer til lyset, for at det skal åbenbares, at hans gerninger er gjort i Gud (3,20f). Efter dette afsluttes afsnittet ved en stedmarkør, da Jesus og hans disciple går til Judæa $(3,22)$.

To forhold er relevante fra konteksten: For det første forholdet mellem v. 16 og v. 17 :

v. 16

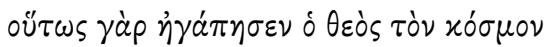

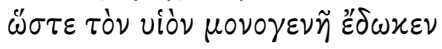

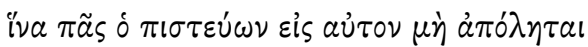

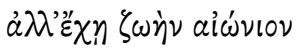

\section{v. 17}

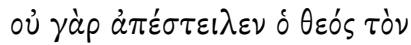

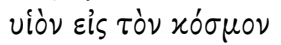

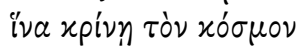

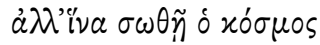

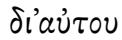

Guds handling mod verden udtrykkes med to forskellige verber i de to vers: didômi og apostellô. Objektet er begge steder ton hyion. Målet for handlingerne er ikke-fortabelse hhv. dom og evigt liv hhv. frelse. Midlet til ikke-fortabelse og frelse er tro på ham hhv. ved ham. Set i sammenhæng med evangeliets sprogbrug i øvrigt, hvor såvel dom og fortabelse som frelse og evigt liv bruges nærmest synonymt, og hvor troen altid fremstilles som adgangen til frelsen (fx 12,44-50), kan der ikke være tvivl om, at de to vers udtrykker den samme intention vedrørende Guds søns komme til verden. Hvis der er en indholdsmæssig forskel mellem v. 16 og v. 17 består den alene i forskellen mellem verberne didômi og apostellô.

didômi optræder ikke i Johannesevangeliet i lignende sammenhænge. Det er overhovedet eneste gang det anvendes med Gud som subjekt og sønnen som objekt. Alle andre steder, hvor Gud er subjekt for didômi, er sønnen, Jesus eller menneskesønnen modtager af gaven. Objektet kan være gerninger $(5,36 ; 17,4)$, magt $(17,2)$, ord $(17,8)$, logos $(17,14)$, herlighed $(17,22.24)$, en form af pas $(6,37.39 ; 17,2)$ eller et pronomen (17,6.7.22). I de fleste tilfælde anvendes verbet for at tilkendegive, at Jesus har fået noget og nogle af faderen. Han skaber et fællesskab mellem dem og Gud ved at overbringe dem, hvad han 
selv har fået (fx tydeligt i 17,6-8 og 17,22). Intet sted handler det om, at sønnen er en gave.

Ikke desto mindre er det langt fra ualmindeligt i Johannesforskningen at tolke verbet, som Davidsen gør, dvs. som en hengiven af sønnen i døden. ${ }^{25}$ Man skulle i det tilfælde forvente, at verbet paradidômi var anvendt (jf. Rom 8,32). Når det ikke er tilfældet, forklares det oftest med, at Johannesevangelisten har en tendens til ikke at anvende sammensatte ord. ${ }^{26}$ Tilbage bliver alligevel det faktum, at udtrykket er singulært i Johannesevangeliet, hvor ingen andre formuleringer bærer det indhold, som Davidsen og ligesindede vil indlæse i verbet didômi i 3,16.

apostellô anvendes derimod typisk johannæisk i 3,17. Mange andre steder i Johannesevangeliet har det nøjagtigt samme betydning ( $f x$ 3,34; 5,36.38; 6,29.57; 7,29; 8,42; 17,2.18). En næsten identisk formulering om sendelsen til verden findes i 10,36. At faderen har sendt sønnen er en så fast formulering i evangeliet, at det næsten har karakter af et guddommeligt epitheton. Spørgsmålet er, hvad sendelsen omfatter. En mulighed er, at den alene omhandler Jesu komme til verden. Således er sendelsen i virkeligheden identisk med inkarnationen $(1,14)$. Men det er tillige muligt at forstå sendelsen som omfattende hele Jesu jordiske eksistens inklusive korsdøden. Argumentet for den tolkning, som er afgørende i R. Bultmanns udlægning ${ }^{27}$, er at finde i det forhold, at selve sendelsen bliver objekt for tro (17,8.21.23.25). Når erkendelsen af Guds autoritet bag Jesu sendelse bliver den tro, som Jesus efterspørger (jf. også 11,42), kan det ikke være begrænset til selve hans komme til jorden, men må omfatte hans død og opstandelse. Hvis ikke det er hele hans eksistens, der omfattes af troen, synes det ikke meningsfuldt at tale om den tro som målet for hans virke. I Bultmanns sprog hedder det, at hans kommen og gåen hører sammen i en enhed, der udgør den eskatologiske begivenhed (Bultmann 1984, 390).

Den mest nærliggende tolkning af forholdet mellem verberne edôken og apesteilen i v. 16 og 17 er derfor, at de er synonyme (Davidsen ville sige: parasynonyme): At Gud giver sin søn, er simpelthen, at han sender sin $s ø n .{ }^{28}$ Det typisk johannæiske udtryk "sende sin $s ø n$ "

25. Fx Helge Kjær Nielsen, Kommentar til Johannesevangeliet (DKNT 4; Aarhus: Aarhus Universitetsforlag 2007), 155.

26. Fx Jörg Frey, Die johanneische Eschatologie. Band III: Die eschatologische Verkündigung in den johanneischen Texten (WUNT 117; Tübingen: Mohr Siebeck 2000), 287.

27. Rudolf Bultmann, Theologie des Neuen Testaments (Tübingen: J.C.B. Mohr (Paul Siebeck) 1984 (9. udgave)), 385-392.

28. Det er der naturligvis ikke enighed om, se Frey (2000), 286. 
bestemmer, hvad der ligger i den singulære og ujohannæiske formulering "at give sin $s ø n$ ". 29

Den anden iagttagelse fra konteksten er nok så interessant. Jesus gives til eller sendes til en verden, som har frelsesbehov. Som det fremgår umiddelbart efter v. 17, viser det sig ved, at menneskene ikke kommer til lyset, selv om det er kommet til verden, men foretrækker mørket frem for lyset. Og selve dette er dommen, som gennem Jesus kan undgås, at forblive i mørket (3,19-21). Mange andre steder i Johannesevangeliet fremstilles verdens situation på lignende måde. Dens tilstand afsløres, når den ikke modtager Guds udsendte. ${ }^{30}$

Davidsen har flere gange med rette bemærket, at det ikke forklares, hvorfor verden er i denne miserable situation (Davidsen 2015, 128 note 4, 143). Som nævnt er det grunden til, at han forudsætter Adam-myten som baggrund for Johannesevangeliet. Imidlertid er der grund til at påpege et væsentligt forhold. I Romerbrevets AdamKristus-typologi er resultatet af Adams overtrædelse en degression i de dynamiske modaliteter (Davidsen 1992, 255f). Mennesket får et problem med dets kunnen pga. den synd, som Adam bringer ind i verden. Gennem denne synd ændres dets værensstatus, så det bliver hjemfalden til død. I Johannesevangeliet er det anderledes. Uanset hvilket dys-angelium der måtte ligge bag Johannesevangeliet, er dets konsekvenser kognitivt modaliseret. Mennesket har problemer med dets viden i Johannesevangeliet. Det er den deficiente vidensmodus, som evangeliet identificerer med en deficient værensstatus: De forstår (ginôskô) ikke $(1,10 ; 8,43.55 ; 10,6 ; 16,3 ; 17,25)$, hører ikke $(8,43.47$; $9,37 ; 10,8)$, ved (oida) ikke $(7,28 ; 8,14.19)$ og tror ikke $(5,38 ; 6,36$; $8,24.45 .46 ; 10,25.37 .37$ etc.). Det er synd i Johannesevangeliets forstand (16,9; jf. 9,41; 15,22.24), og i synden dør man også ifølge Johannesevangeliet $(8,21.24)$. Den tilstand kan kun ændres ved at forstå $(7,17 ; 8,27.28 .32 ; 10,14.15 .38 ; 14,7.20 .31 ; 17,3.7 .8 .23)$, høre $(5,24$; $6,45 ; 10,3.16 .27 ; 12,47 ; 14,24 ; 18,37)$, se $(6,30 ; 12,45 ; 14,9)$ og tro $(11,40.42 ; 12,44.46 ; 13,19 ; 14,29 ; 16,27 ; 17,8$ etc.). Den privilegerede vidensstatus er ækvivalent med en privilegeret værensstatus, dvs. den

29. Man kan her overveje Davidsens ide, at Johannesevangeliet er en "dekonstruktion" af traditionelle forestillinger (jf. citatet ovf.). Forholdet kunne være, at evangelisten overtager en traditionel hengivelsesformel i v. 16 og indholdsbestemmer den johannæisk i v. 17. Modsat Frey (2000), 286f, der mener, at evangelisten overtager en traditionel sendelsesformel og omdanner den til en hengivelsesformel i 3,16. Det forekommer dog bagvendt, al den stund sendelsesformlen uden konkurrence er den mest dominerende i evangeliet og derfor vel må anses for at være johannæisk.

30. Det er det forhold, der i Johannesforskningen traditionelt går under betegnelsen "die Präponderanz des gottlichen Heilswillens", Josef Blank, Krisis. Untersuchungen zur johanneischen Christologie und Eschatologie (Freiburg i.B.: Lambertus Verlag 1964), 88. 
troende har evigt liv $(3,15.36 ; 5,24 ; 6,40.47 ; 11,25.26)$ og er frelst for dom $(3,18 ; 5,24 ; 12,47)$. Det evige liv defineres følgelig som at kende (ginôskô) Gud og hans udsendte, Jesus Kristus (17,3). De ikke-troende derimod forbliver i den deficiente status, som ofte er metaforiseret som mørket, der afviser lyset (3,18-21.36; 12,46-48, jf. 1,5). Slutter man bagud i henhold til den narrative logik post hoc ergo propter hoc, ${ }^{31}$ ligger der et dys-angelium bag Johannesevangeliet, hvor en degressiv kognitiv handling etablerer en deficient værensstatus, for i eu-angeliet etablerer en progressiv kognitiv handling den privilegerede værensstatus. I modsætning til den paulinske Adam/Kristus-myte skal den degressive handling derfor ikke findes i den pragmatiske dimension, men i den kognitive, for deri findes den progressive handling. Gaven er den progressive handling, for den giver muligheden for at kende Gud.

\section{Modtagelse og indhold af den johannæiske gave}

Med denne tolkning af Joh 3,16 synes vejen åbnet for en teologi, som den kendes fra gnostiske skrifter, fx Evangelium Veritatis. Hvad der mangler, er erkendelsen af Gud. Fordi Gud ikke er kendt, kommer glemslen, synd, frygt og angst ind i verden. Frelser- og åbenbaringsfiguren, Jesus, bringer derfor erkendelse af Gud. Da han hænges på et træ, bliver han erkendelsens frugter. ${ }^{32}$ Den grundlæggende teologiske struktur er helt klar i skriftet og udtrykkes koncist: "Fordi manglen (engelsk oversættelse: "deficiency") blev til, da man ikke kendte faderen, så skal det ske, når man kender faderen, at manglen fra det øjeblik ikke længere skal være til” (EvVer 24,28-32). Her kan det ikke være tydeligere, at både dys-angeliet og eu-angeliet er kognitive begivenheder. Man kan med god grund mene, at sådanne udviklinger er konsekvente fortolkninger af Johannesevangeliet, som ikke kan siges at være mere i strid med evangeliet end så mange andre senere teologiske former. Alligevel er det værd at fremhæve forskelle mellem Evangelium Veritatis og Johannesevangeliet. Det kan vises ved at udlægge den gave, som Gud ifølge 3,16 giver og er lig med den sendelse, som Gud ifølge 3,17 står bag. Særligt to forhold tematiseres ikke på samme måde i Johannesevangeliet og Evangelium Veritatis: modtagelsen af gaven og indholdet af den.

31. Jf. Roland Barthes, "Introdution à l'analyse structurale des récits", Communications 8 (1966), 1-27 (10).

32. Se hertil Katrine Brix, "Kosmoskreuz oder Holzkreuz im Evangelium Veritatis NHC I,3?”, i Christoph Markschies, Johannes van Oort (red.), Zugänge zur Gnosis (Leuven: Peeters 2013), 151-167. 
Modtagelsen er et mindre behandlet aspekt af gavegivningen. Det ses alene af præsentationen af Derridas ide om gaven, nemlig som en, der hverken gives eller modtages. Tværtimod forsvinder den i samme øjeblik. Som nævnt kan det være en underliggende protestantisk tilgang til gavegivning, der lader økonomi stå i modsætning til gave. Som sagt, har det for Derrida den konsekvens, at gaven aldrig kan vise sig eller erkendes som gave, for derved har den opløst sig selv som gave. "La simple identification du don semble le détruire" (Derrida 1992, 26). Det betyder, at netop gave-givning som en social begivenhed udelukkes. Gaven kan ikke indgå i interpersonelle relationer, for netop deri udelukkes gaven som gave, selv om den forudsætter dem for at være gave. Hermed bliver Derridas gavebegreb stik modsat den opfattelse af gaver, som var gældende i antikken. Her var det nemlig afgørende, at gaver etablerer venskaber. Forestillingen om den ensidige, uselviske gave var ikke afgørende. Det var tværtimod opfattelsen af gaven som en social begivenhed.

Senecas storværk om gaver eller velgerninger (de beneficiis) gennemgår at give (beneficium dare), modtage (beneficium accipere) og gengælde (beneficium redere) gaver samt at udvise taknemmelighed (gratiam referre) og lægger afgørende vægt på det interpersonelle aspekt. ${ }^{33}$ Afgørende for Seneca er holdningen i gaverelationen. Både giver og modtager skal have det rette sind (animus). Giveren skal ikke være skødesløs, modvillig eller nedladende (ben 1.1.4-8). Modtageren skal være taknemmelig (ben 4.40.1) og gengælde gaven (ben 2.18.5). Det er den forståelse mellem giver og modtager (ben 1.1.8), der sikrer, at gaver fungerer inden for en personlig relation. Den personlige og interpersonelle essens er afgørende for udredningerne. Ved at give og modtage gaver oprettes, vedligeholdes og udtrykkes et personligt forhold mellem de to involverede parter (fx ben 2.18.5; 6.16.1-7). Gaver skal være personlige (fx ben 6.18.1-2). Men man kan ifølge Seneca modtage en gave uden at vide det og uden at ville det (ben 6.8.1). Det kan man fx se på forældres opdragelse af deres børn. Børnene er vrangvillige og alligevel er opdragelsen en velgerning mod dem, mener Seneca. De bliver senere klar over det og kan returnere gaven ved taknemmelighed, som man bør respondere på en gave (ben 6.24.1-2).

Belært af Derrida er forholdet nok snarere, at gaven kan gives, selv om modtagelsen af opdragelsen som gave er forskudt i forhold til gavetidspunktet. Det synes nemlig afgørende for gavestrukturen, at den anerkendes som gave, selv om det netop er dette strukturelle forhold i gavegivningen, der ifølge Derrida umuliggør gavens tilsynekomst:

33. Tekst og oversættelse i Seneca, Moral Essays III (LCL, Cambridge, Mass.: Havard University Press 1975). Se til præsentationen af Senecas forstålse EngbergPedersen (2008), 18-21; Saarinen (2010), 278-282. 
“... cette simple reconnaissence suffit pour annuler le don" (Derrida 1992, 26). For det er den gensidige anerkendelse i gavegivning, der etablerer det reciprokke forhold, som er problematisk for Derrida. For at være en gave, må giveren anerkendes som giver og modtageren som modtager. Således oprettes og vedligeholdes interpersonelle forhold gennem gavegivning. Derfor er det en prekær situation at modtage en gave. Hermed etableres den sociale relation, som Seneca kalder venskabsforhold. Uden den gensidige anerkendelse opstår det forhold ikke. Giveren kan ikke give gaven, og modtageren kan ikke modtage den. Eller: Giveren kan ikke slippe af med den, og modtageren kan ikke slippe for den. I så fald perverteres forholdet mellem dem. Gaven kan blive et overgreb eller et rov.

Bag gaven i Johannesevangeliet ligger samme logik. Gaven er erkendelsen af faderen gennem den udsendte søn. Først når Gud anerkendes som giveren af gaven, og mennesket anerkender sig selv som modtageren, kan gaven gives og modtages. Derved opløses den deficiente vidensmodus, som i Johannesevangeliet er lig dom og død, og en privilegeret værensstatus indtræder. Den består i relationen mellem giver og modtager stiftet gennem gaven, hvilket Johannesevangeliet kalder evigt liv. Med til gaven hører også en forpligtelse, som hos Seneca er gengæld. I Johannesevangeliet udtrykkes det som en pligt til at opfylde det nye bud, som Jesus giver dem $(13,34 \mathrm{f})$, som netop er begrundet i den kærlighed, som de har fået.

Indholdet af gaven blev ovenfor defineret som Jesu sendelse, dvs. hele hans jordisk eksistens. Korsdøden udgør ikke gaven alene, men er en del deraf. I Jesu jordeliv ligger en narrativ struktur, hvor opgaven er at fremkalde anerkendelse af Gud. ${ }^{34}$ Det sker, når troen på, at Gud er autoriteten bag Jesu virke, er fremkommet. Målet ligger i den kognitive dimension, og den pragmatiske bidrager dertil. Korsdøden er nemlig nødvendig, for at den opstand ne Kristus kan overbevise disciplene ved sine stigmata $(20,20.29)$. Det samme er Jesu handlinger $(2,11.23 ; 6,14.26 ; 11,42 ; 12,37)$ og hans tale $(8,28 ; 14,10 ; 15,22.24$; 17,8.14). Hele hans virke er rettet mod at åbenbare Gud og fremkalde troen på, at han åbenbarer Gud. Her melder spørgsmålet sig, hvorledes denne åbenbaring finder sted, og hvad dens indhold er. Med andre ord er spørgsmålet, hvordan den semiotiske relation mellem det pragmatiske og det kognitive niveau skal forstås.

Bultmann svarer som bekendt konsekvent, at Jesus intet åbenbarer ud over, at han er åbenbareren (Bultmann 1984, 418). Hans tale handler kun om hans relation til faderen (Bultmann 1984, 414) og

34. Jesper Tang Nielsen, Die kognitive Dimension des Kreuzes. Zur Deutung des Todes Jesu im Johannesevangelium (WUNT 2/263; Tübingen: Mohr Siebeck 2009). 
hans handlinger er intet andet end synlige ord (Bultmann 1984, 412). Således kan hele Jesu gerning sammenlignes med en gnostisk åbenbaringstale med den forskel, at der ikke åbenbares konkrete hemmeligheder om skabelsen og frelsen. Åbenbaringen er tom og stiller derfor modtageren over for afgørelsen (Bultmann 1984, 419). Den johannæiske Jesus åbenbarer Gud, men hans konkrete jordiske liv har ingen betydning som andet end et faktum. Derfor har korsdøden heller ingen betydning for Bultmann. Den er kulminationen og afslutningen på den menneskelige eksistens, men den bærer ingen selvstændig værdi (Bultmann 1984, 405). Med andre ord er forholdet mellem de ydre tegn, mirakler, korsdød og opstandelse, og budskabet lige så tilfældigt som mellem det talte ord og dets betydning. Tegnet er arbitrært, og dets relation til det betegnede er konventionelt. Bultmanns opfattelse står ikke stærkt i den aktuelle Johannesforskning, men der er ikke fremkommet gennemarbejdede alternative svar på spørgsmålet. Det følgende er et forsøg på at svare ved hjælp af Charles Sanders Peirces semiotik.

Peirce udarbejder i sit forfatterskab flere forskellige tegndefinitioner. En af de mest præcise og samtidigt komplekse er den følgende:
A Sign, or Representamen, is a First which stands in such a genuine triadic relation to a Second, called its Object, as to be capable of deter- mining a Third, called its Interpretant, to assume the same relation to its Object in which it stands itself to the same Object. ${ }^{35}$

Når han videre skal definere relationen mellem tegnet og dets betegnede, sondrer han mellem tre fundamentale tegntyper. Et ikon er et tegn på grund af kvalitet, så dets tegnfunktion består af lighed med det betegnede. Et billede kan være tegn for en person, fordi det ligner denne person. Den anden tegntype kaldes et indeks. Det er tegn i $\mathrm{kraft}$ af dets eksistens, fordi det er forbundet med dets betegnede i en konkret relation. Eksempelvis er vejrhanen tegn for vindretningen, fordi den er direkte forbundet med vinden. Den tredje type er symbolet. Dets relation til objektet er lovmæssigt. Et eksempel er det røde trafiklys, som kun på grund af konvention betyder stop. ${ }^{36}$

35. Charles Sanders Peirce, "Sundry Logical Conceptions", i The Essential Peirce. Vol. 2 (1893-1913) (Bloomington, IN: Indiana University Press 1998), 267-288 (272f).

36. Bultmanns opfattelse af forholdet mellem det pragmatiske og kognitive niveau kan ud fra disse kategorier bestemmes som symbolsk. Det pragmatiske niveau er tegn for åbenbaringen, men det giver ikke i sig selv nogen oplysninger om det, som det betegner. 
I Johannesevangeliet er Jesus tegn for Gud. Gennem ham kommer mennesker til at kende Gud. Sønnen repræsenterer i en tegnrelation faderen. Ud fra Peirces semiotik kan man analysere den johannæiske Jesu semiotiske identitet ret præcist. ${ }^{37}$ Der er ingen tvivl om, at forholdet mellem tegn og objekt er eksistentielt. Det fremgår tydeligt af flere formuleringer i evangeliet, at faderen og sønnen er forbundet $i$ en værensrelation ( $f x$ 14,10.11). Det er ved sin konkrete eksistens, at sønnen kan stå for faderen, som et tegn står for objektet. Jesus er derfor ifølge Peirces semiotik et indeks, når han betegner Gud. Men han optræder som Guds tegn i en fortælling, fordi denne fortælling skal give indhold til hans tegnfunktion. Det viser sig nemlig i Johannesevangeliets fortælling, at han ikke kan fremkalde den ønskede tro, før hans gerning er fuldbragt (19,30). Først i kraft af sin død og opstandelse opnår han den kvalitet, der skal til for at betegne Gud. Hans frivillige død $(10,11.17 f ; 15,13)$ er en integreret del af hans virke $(12,27 ; 18,11 ; 19,30)$, fordi den er nødvendig for hans åbenbaring af Gud. Derfor henviser han flere gange til en kommende erkendelse, der først følger efter hans død og opstandelse $(8,28.32 ; 13,7 ; 14,20)$. Således antager den pragmatiske dimension i Johannesevangeliet ikonisk karakter for den kognitive dimension, idet den er et tegn på grund af kvalitativ lighed. ${ }^{38}$ Jesus meddeler noget om Gud, fordi han $i$ en vis forstand ligner ham $(12,45 ; 14,9)$. Åbenbaringen ville være en anden, hvis Jesu mirakler alene var forbandelser!

På denne baggrund bliver det forståeligt, hvordan den johannæiske Jesus kan udfylde sit nye bud $(13,34 \mathrm{f})$ som viljen til at give sit liv for sine venner $(15,12 \mathrm{f})$. Det er netop, fordi indholdet af den gave, som Gud giver, bestemmes kvalitativt gennem Jesu pragmatiske virke, at forpligtelsen til at gengælde gaven også er indholdsbestemt derigennem.

\section{Udveksling og gave i det johannæiske dys-angelium}

Med denne fortolkning af gavegivningen i 3,16 kan man sige noget om baggrunden for den situation, som gaven forbedrer. Eu-angeliet består i den gave, der dels kræver anerkendelsen af Gud som giveren og mennesket som modtageren, dels indeholder en åbenbaring

37. Jesper Tang Nielsen, "The Secondness of the Fourth Gospel - A Peircean Reading”, StTh 60 (2006), 123-144.

38. Teknisk udtrykt er den johannæiske Jesus et Sin-tegn, som indeholder et Qualitegn, der udgøres af hans jordiske eksistens. Nielsen (2006), 133 f. 
af Gud. Dys-angeliet må da være det modsatte: dels afvisningen af Gud som giveren og mennesket som modtageren, dels ukendskab til Gud. I Romerbrevet findes et udtryk for netop denne situation. Paulus siger: "For de kendte Gud, og alligevel ærede (edoxasan) og takkede de ham ikke som Gud; men deres tanker endte i tomhed, og de blev formørket i deres uforstandige hjerte" (Rom 1,21). Denne model indeholder en manglende modtagelse af en gave som en gave (de takkede ikke) og dermed en manglende anerkendelse af den sociale relation mellem giver og modtager (de ærede ikke), hvilket medfører et kognitivt deficit (deres tanker endte i tomhed og de blev formørket i deres uforstandige hjerte), som frem for modellen i Rom 5 kan ligge bag Johannesevangeliet. ${ }^{39}$

Udlægger man denne dys-angeliske fortælling gennem de udvekslingsteoretiske bestemmelser, som Davidsen har anvendt, får man et anderledes forløb end i Adam-myten. Initialsituationen er bestemt af Guds krav om tak og ære, dvs. anerkendelse af ham som Gud. Menneskene burde give ham hans berettigede anerkendelse (Manipulation). Men det sker ikke. De giver ham ikke anerkendelse. Det er en illegitim ikke-given, fordi den står over for Guds legitime tagen. ${ }^{40}$ Ikke at give den berettigede gave svarer til at modsætte sig den sociale relation mellem parterne. ${ }^{41}$ Mod den berettigede forventning giver menneskene ikke den legitime gave, men forholder Gud anerkendelsen (Performance). Fordi de ikke anerkendte Gud, overgives de til tomhed og mørke. Det svarer til, at Gud på grund af deres illegitime ikke-given udøver en legitim ikke-given ved ikke at give dem den rette erkendelse. Han giver dem ikke, hvad de ikke er berettiget til (Sanktion). Som fremstillet ovenfor medfører sanktionen en kognitiv degression, som svarer til en ontologisk degression, fordi mørket, dommen og døden ifølge Johannesevangeliet netop er ikke at kende Gud.

På baggrund af dette dys-angelium er eu-angeliet i Joh 3,16 fuldt forståeligt. Gud ophæver sanktionen ved at give erkendelsen af sig gennem sin enbårne søn. I modtagelsen af den gave ligger imidlertid

39. Det litterære forhold mellem Paulus og Johannesevangeliet er ikke relevant for denne tolkning, ligesom det ikke er i Davidsens udlægning. Pointen her er blot, at der findes kognitive dys-angelier.

40. Det kan også defineres som en illegitim tægt, fordi ikke-given er en form for tagen, nemlig at tage noget for sig selv, som skulle være givet til den anden, jf. Davidsen (2013), 124.

41. En sådan ikke-given beskriver Davidsen (2013), 124: "Denn was könnte ein sinnvolles Nicht-Geben sein, wenn nicht ein Bruch in der Erwartung, eine positive Rückzahlung als Anerkennung und Belohnung zu empfangen? ... Dem Anderen nicht zu geben, was man ihm oder ihr schuldig ist, kann dem entsprechen, dass der Andere der Erfüllung einer wohlbegründeten Lebenserwartung beraubt wird.” 
også en omgørelse af den fejlslagne performance. For selve modtagelsen af gaven kræver som nævnt en anerkendelse af gaven som en gave, hvilket svarer til at give Gud den berettigede anerkendelse. ${ }^{42}$

\section{Afslutning}

Fortolkningen af Joh 3,16 gennem udveksling- og gaveteorier fremviste evangeliets grundlæggende struktur.

1. Gud giver sin søn som gave til verden. For at gaven skal realiseres som gave, skal modtageren anerkende den som gave. Gaven består af erkendelse af Gud gennem Jesus. Derfor hører hele Jesu liv og virke med til gaven. Derved opnår han den kvalitet, som giver den rette erkendelse af Gud.

2. Bag denne struktur i Johannesevangeliet ligger en dys-angelisk struktur, hvor mennesker ikke anerkender Gud som Gud. Derved nedbrydes relationen mellem Gud og mennesker. Det kaldes død i evangeliet.

3. Når gaven modtages, anerkendes Gud som Gud, og faderen erkendes gennem sønnen. Derved etableres den rette relation mellem Gud og mennesker. Det kaldes evigt liv i evangeliet.

Værdien af Davidsens udvekslings- og gaveteoretiske udredninger er tydelig også for Johannesevangeliets vedkommende, selv om strukturerne ikke, som han tror, findes i den pragmatiske dimension. Gaven er kognitiv. Den giver den erkendelse, der er evigt liv. Johannesevangeliet fortæller ikke samme historie som Markusevangeliet og har ikke samme teologi som Paulus. Men det behøver ikke at være en pinefuld skandale.

42. Johannesevangeliet beskriver også denne struktur med herlighedsterminologi, som kan oversættes i anerkendelsestermer. Jf. Jesper Tang Nielsen, "Første forsøg på en anerkendelsesteoretisk fortolkning af Johannesevangeliet”, i Søren Holst, Christina Petterson (red.), Den store fortalling. Festskrift til Geert Hallbäck (København: Anis 2012), 185-200; "The Narrative Structures of Glory and Glorification in the Fourth Gospel”, NTS 56 (2010), 343-366. 